\title{
Ocena jakości życia pacjentów z kolostomią
}

\author{
The assesment of quality of life in patients with colostomy
}

\author{
KATARZYNA GĘSICKA ${ }^{1}$, MONIKA RYCHLEWSKA ${ }^{2}$, TERESA \\ SIEMIANOWSKA ${ }^{2}$
}

\author{
1 Podstawowa Opieka Zdrowotna „Pomed” Czernikowo \\ ${ }^{2}$ Instytut Nauk o Zdrowiu Państwowej Wyższej Szkoły Zawodowej we Włocławku \\ 3 Odział Chirurgii Ogólnej, Wojewódzki Szpital Specjalistyczny im. Bł. ks. J. Popiełuszki \\ we Włocławku
}

DOI: http://dx.doi.org/10.21784//wP.2019.007

ISSN:2451-1846

\section{Streszczenie:}

Wstęp. Pierwsze wzmianki dotyczące stomii jelitowej pochodzą sprzed trzech tysięcy lat. Z upływem czasu zmieniły się techniki, mechanizm jak i przyczyny wyłonienia kolostomii, lecz emocje towarzyszące jej wytworzeniu pozostały na porównywalnym poziomie. Wydawać by się mogło, że skoro szybki rozwój nauk medycznych dał możliwość efektywnego leczenia chorób wcześniej uznanych za nieuleczalne, to zmniejszy się również liczba osób z wyłonioną kolostomią. Niestety, w następstwie szybkiego rozwoju cywilizacyjnego zwiększa się liczba zachorowań na raka jelita grubego, co z kolei stanowi główną przyczynę wytworzenia stomii jelitowej.

W ostatnich latach, badania dotyczące oceny jakości życia znacznie zyskały na znaczeniu ze względu na holistyczne i interdyscyplinarne spojrzenie na sytuację chorego. Badania nad jakością życia są nie tylko przejawem troski o dobro pacjenta, lecz także wyrazem zaangażowania ludzi reprezentujących wiele zawodów, zarówno medycznych jak i humanistycznych.

Cel. Celem pracy jest analiza wybranych obiektywnych oraz subiektywnych czynników, wpływających na ocenę jakości życia osób z wyłonioną kolostomią. Materiał i metody. W badaniach zastosowano metodę sondażu diagnostycznego. Jako technikę dla skonkretyzowania zamiarów badawczych 
wybrano ankietę. Za narzędzie badawcze posłużył charakterystyczny dla oceny jakości życia - kwestionariusz ankiety.

Do analizy statystycznej wykorzystano test niezależności chi - kwadrat (zwany inaczej testem Pearsona) służący sprawdzaniu hipotez. W opracowaniu danych wykorzystano również korelację rang Spearmana (rho - Spearmana). Badaną grupę stanowiły 82 osoby z kolostomią $\mathrm{w}$ różnym okresie po leczeniu operacyjnym, w tym 38 kobiet $(46,34 \% \approx 46 \%)$ i 44 $(53,66 \% \approx 54 \%)$ mężczyzn.

Wyniki. Na podstawie otrzymanych wyników i ich analizy stwierdzono, że jakość życia wśród respondentów jest niska. Czynniki socjodemograficzne takie jak: płeć, wykształcenie, miejsce zamieszkania są wprost proporcjonalne i wywierają na tę ocenę istotny wpływ. Analiza statystyczna wykazała również znaczący wpływ otrzymywanego wsparcia społecznego ma wpływ na ocenę jakości życia.

Wnioski. Osoby z wytworzoną kolostomią reprezentują obniżony poziom jakości życia. Na taki stan rzeczy, w takim samym stopniu, wywierają wpływ obiektywne czynniki społeczno - ekonomiczne, kliniczna ocena choroby jaki subiektywne poczucie jakości życia. Szczególne znaczenie wywiera przynależność chorych do Polskiego Towarzystwa Stomijnego oraz wsparcie otrzymywane od jego członków.

Słowa kluczowe: jakość życia, opieka, kolostomia

\begin{abstract}
:
Introduction. The first mention of stoma dates back three tousand years. With time the techniques, mechanism as well as reasons for stoma have changed. The emotions and feelings that accompany the stoma remain unchanged. It may seem that the developments in health technologies and medical studies have given the opportunity to provide effective treatment in the case of diseases originally considered incurable and the number of people with stoma will decrease. Unfortunately, following the civillisation development the number of cases of colorectal cancer is growing, which constitues a major cause of stoma.

Studies devoted to the quality of life have grown in significance in recent years and this is due to holistic and interdisciplinary approach towards patients. Studies on the quality of life are not only about the dispaly of patietn care but
\end{abstract}


also a sign of commitment of people representing different professions, both within the fields of humanities and medicine.

Aim. The aim of the study is to analyze selected objective and subjective factors affecting the quality of life in patients with stoma.

Material and Methods. The diagnostic survey togethether with a survey was used to make the study more specific. Also a questionnaire on the quality of life in patients wtih stoma was a research tool. A Chi- squere test ( Pearson's test) was used in statistical analysis. The collected data were estimated using the Spearman rank correlation. The respondents consisted of 82 people with stoma at different stages after post-operative treatement, inlcuding 38 women $(46,34 \% \approx 46 \%)$ and $44(53,66 \% \approx 54 \%)$ man.

Results. The results obtained together with their analysis stated that thequality of life in respondets is low. Socio-demographic factors such as : gender, education and place of residence are directly proportional to the results and have a significant impact on the assesment of the respondents' quality of life. Statistical analisys showed that social support is of great importance to the respondents and contributes significantly to their assesment of the quality of life.

Conclusion. Patients with stoma have reduced quality of life. This is due to objective socio-economic factors, clinical evaluation of the disease as well as subjective assesment of quality of life . It is also particularly important if a patient is a member of Polish Ostomy Association and can rely on their support.

Keywords: quality of life, nursing care, stoma

Wstęp

Termin stomia wywodzi się z języka łacińskiego i oznacza usta, otwór czy przetokę. Nazwy tej używa się do określenia sztucznie wytworzonego połączenia pomiędzy narządem jamistym powierzchnią błony śluzowej lub skóry. Taki rodzaj połączenia wytwarza się wobrębie różnych układów np. moczowego, pokarmowego czy oddechowego [1]. W przypadku kolostomii mówimy o połączeniu światła jelita grubego ze skórą powłok jamy brzusznej, które zostaje wykonane w czasie zabiegu chirurgicznego, w trybie 
nagłym lub planowym. Taki rodzaj stomii jelitowej nazywany jest również zewnętrzną przetoką jelitową, odbytem brzusznym, anusem brzusznym lub częściej sztucznym odbytem $[2,3]$.

Kolostomia jest najczęściej wykonywanym rodzajem stomii jelitowej, która polega na wyprowadzeniu ponad powłoki brzuszne końca jelita grubego. Stanowi ona nowe ujście, przez które następuje wydalanie kału. Sytuacja taka ma miejsce wówczas, gdy zmiany chorobowe jelit uniemożliwiają prawidłowe funkcjonowanie układu pokarmowego i wymagają częściowej jego resekcji lub odbarczenia. Wyłonienie stomii bez względu na jej charakter oraz czas trwania pociąga jednak za sobą trudne do zaakceptowania przez pacjenta konsekwencje. Są to nie tylko skutki fizyczne, które związane są z wyglądem ciała, utratą kontroli nad wydalaniem stolca i gazów, ale również problemy emocjonalne, społeczne i psychiczne wynikające z konieczności adaptacji do nowej sytuacji spowodowanej chorobą oraz zabiegiem operacyjnym [4]. Wyłonienie kolostomii może stanowić trudne do zaakceptowania przez samego chorego okaleczenie, które nierzadko ma odzwierciedlenie w późniejszym jego funkcjonowaniu $\mathrm{w}$ różnych sferach życia. Zmianie ulega akceptacja własnego ciała, samoocena oraz często sytuacja życiowa [4]. Poza fizycznym przygotowaniem pacjenta do zabiegu, ważne jest zatem przygotowanie psychiczne, które rozpoczyna się $\mathrm{z}$ chwilą poinformowania chorego o konieczności przeprowadzenia operacji. Polega ono głównie na wyjaśnieniu wszelkich wątpliwości, udzieleniu wsparcia emocjonalnego, wysłuchaniu obaw chorego oraz pomocy w przygotowaniu się do samoopieki i samopielęgnacji. Istotne w przygotowaniu psychicznym jest poznanie oraz zrozumienie niepokojów i obaw pacjenta, zindywidualizowane traktowanie, zapewnienie poczucia bezpieczeństwa oraz wskazanie i ułatwienie kontaktu z osobami kompetentnymi w wyjaśnianiu wątpliwych kwestii [5]. 
Celem niniejszej pracy jest analiza wybranych obiektywnych oraz subiektywnych czynników wpływających na ocenę jakości życia osób z wyłonioną kolostomią.

\section{Materiał i metody}

W pracy zastosowano metodę sondażu diagnostycznego. Jako technikę dla skonkretyzowania zamiarów badawczych wybrano ankietę. Za narzędzie badawcze posłużył charakterystyczny dla oceny jakości życia kwestionariusz ankiety autorstwa dr. med. Zbigniewa Banaszkiewicza i współautorow, na którego wykorzystanie otrzymano zgodę autora [8]. Ankieta ta zawiera 25 pytań. Na potrzeby bieżącej pracy dodano dwa pytania dotyczące otrzymywanego wsparcia oraz przynależności badanych do grupy zrzeszającej osoby z kolostomią. Końcowa wersja, jaką respondent otrzymał do wypełnienia zawierała zatem 27 pytań.

Pierwszą część kwestionariusza stanowiła metryczka zawierająca pytania, które dotyczyły: wieku, płci, wykształcenia, charakteru pracy, miejsca zamieszkania respondentów. Kolejne pytania odnosiły się do przyczyn wyłonienia kolostomii, przygotowania do samopielęgnacji, kontaktu z personelem ochrony zdrowia, oceny stanu zdrowia po zabiegu operacyjnym, ograniczeń w kontaktach osobistych i wykonywaniu czynności dnia codziennego w związku z wyłonieniem kolostomii. Pacjent odpowiadał również na zagadnienia dotyczące pracy zawodowej, zainteresowań, wyglądu zewnętrznego, relacji $\mathrm{z}$ rodziną i znajomymi, kontaktów towarzyskich, warunków ekonomicznych, występowania lęku, korzystania z rozrywek i wypoczynku oraz akceptacji kolostomii.

Badania miały charakter anonimowy. Warunkiem ich przeprowadzenia była dobrowolna zgoda pacjenta na udział w procedurze badawczej.

Wyniki badań poddane zostały szczegółowej analizie statystycznej za pomocą testu niezależności chi - kwadrat (zwany 
inaczej testem Pearsona). Ponadto wykorzystano również korelację rang Spearmana(rho - Spearmana).

Badaną grupę stanowiły 82 osoby z kolostomią $\mathrm{w}$ różnym okresie po leczeniu operacyjnym, w tym 38 kobiet $(46,34 \% \approx 46 \%)$ i $44(53,66 \% \approx 54 \%)$ mężczyzn.

Respondenci pozostawali w różnym przedziale wiekowym. Największą grupę respondentów stanowiły osoby w grupie wiekowej pomiędzy 50 a 60 rokiem życia (36,59\% badanych). Na kolejnym miejscu pod względem liczebności znalazły się osoby między 61 a70 rokiem życia (25 ankietowanych - 30,49\%). Tylko jeden respondent znajdował się w kategorii wiekowej pomiędzy 20 - 30 rokiem życia.

Kolejnym elementem różnicującym ankietowanych pacjentów było wykształcenie. Najwięcej, bo 30 osób posiadało wykształcenie średnie, 26 ankietowanych - zawodowe. Najmniej chorych, bo tylko $10(20,2 \%)$ legitymowało się wykształceniem podstawowym. W pytaniu dotyczącym charakteru wykonywanej pracy chorzy wybierali właściwą dla siebie opcję pośród trzech możliwych: pracownika fizycznego, pracownika umysłowego oraz inne warianty aktywności zawodowej. Tylko dwie osoby nie podały czy są czynne zawodowo. Większość, bo aż 51 pacjentów (62,20\%) przebywało na emeryturze a 9 osób $(10,98 \%)$ na rencie. Pracę w charakterze pracownika umysłowego wykonywało 18 osób, a tylko 2 osoby były zatrudnione jako pracownicy fizyczni. Tak więc w grupie badanych 82 osób tylko 20 było czynnych zawodowo.

Zróżnicowane było również miejsce zamieszkania respondentów. Najliczniejsza, bo 34-osobowa grupa ankietowanych mieszkała w największych miastach $(41,46 \%)$. Drugą pod względem wielkości grupę stanowili mieszkańcy wsi (24 osoby -29,27\%). Najmniej - 9 osób - mieszkało w miastach 50 - 100 tysięcznych. Reasumując, w 82-osobowej grupie, aż 58 osób mieszkało w miastach.

Najwięcej respondentów mieszkało ze współmałżonkiem 35 osób (około 43\%). Z kolei 15 osób zamieszkiwało ze współmałżonkiem i dziećmi a 14 osób z dziećmi i wnukami. 
Samotne prowadzenie gospodarstwa domowego zadeklarowało 21,95\% badanych (18 osób).

Badania przeprowadzono na terenie województwa kujawskopomorskiego, wśród pacjentów Niepublicznego Zakładu Opieki Zdrowotnej „Pomed” w Czernikowie, Niepublicznego Zakładu Opieki Rodzinnej „Na Złotej Górce” w Kikole, Szpitala Lipno Sp. z o. o., Bydgoskiego Oddziału POL - ILKO oraz ART - MED - u, sklepu medycznego realizującego zlecenia na zaopatrzenie stomijne z siedzibą w Toruniu.

\section{Wyniki}

Zdecydowanie jako najczęstszą przyczynę wytworzenia kolostomii respondenci wskazywali nowotwór jelita grubego. Z tego powodu wyłoniono stomię aż u 63 osób. Z kolei 7 pacjentom wyłoniono odbyt brzuszny w następstwie niedrożności mechanicznej. $\mathrm{Na}$ inną przyczynę nie uwzględnioną $\mathrm{w}$ ankiecie wskazało 6 respondentów $(7,32 \%)$. W pojedynczych przypadkach, wskazanie do stomii stanowiły powikłania po zabiegu ginekologicznym, rak pęcherza moczowego, uchyłkowatość oraz polipowatość mnoga. W dwóch przypadkach respondenci nie podali przyczyny.

W momencie podjęcia decyzji o wyłonieniu kolostomii rozpoczyna się edukacja przedoperacyjna pacjenta. Jej celem jest oswojenie chorego $\mathrm{z}$ faktem posiadania nowego ujścia jelita oraz przygotowanie go do okresu pooperacyjnego. Po zabiegu wyłonienia przetoki, pielęgniarka najczęściej jako pierwsza uczy pacjenta zasad pielęgnacji oraz doboru odpowiedniego sprzętu i służy pomocą $\mathrm{w}$ dokonaniu jego właściwego wyboru. Przed opuszczeniem szpitala chory posiada podstawową wiedzę dotyczącą zasad właściwej pielęgnacji stomii. Ogrom przekazanych danych może jednak wpłynąć na to, że pacjent nie jest w stanie zapamiętać uzyskanych informacji oraz zastosować ich w praktyce. Niezbędne wówczas okazują się działania edukacyjne podejmowane $\mathrm{w}$ poradniach specjalistycznych 
czy placówkach podstawowej opieki zdrowotnej (poz). Część pacjentów uzupełnia wiedzę i rozwiewa swoje wątpliwości korzystając z literatury czy informacji dostępnych w Internecie. Szpital nadal jednak pozostaje tym miejscem, gdzie chory otrzymuje podstawową wiedzę niezbędną do prowadzenia samoopieki i samopielegnacji. Tak też odpowiedzieli respondenci na zadane pytanie dotyczące przygotowania do pielęgnacji kolostomii. Zdecydowana większość, bo aż $84,15 \%$ (69 osób) otrzymała takie przygotowanie w szpitalu. Wśród pozostałych 13 osób, w 5 przypadkach była to przychodnia specjalistyczna $(6,10 \%)$, w 3 - przychodnia w poz $(3,65 \%)$. Z kolei 5 pacjentów $(6,10 \%)$ przygotowało się samodzielnie na podstawie literatury.

Bardzo istotnym elementem decydującym często o losach osób z wytworzoną kolostomią jest możliwość dobrego kontaktu z personelem ochrony zdrowia. Pacjent z odbytem brzusznym, który pozostaje otoczony profesjonalną i zespołową opieką we wszystkich okresach swojej choroby, ma szanse na osiągnięcie wysokiej jakości życia po operacji. Wśród ankietowanych 17 osób oceniło swój kontakt z personelem jako bardzo łatwy, 13 pacjentów jako trudny a bardzo trudny - 5 osób. Zdecydowana większość, bo ponad 57\%respondentów określiło ten kontakt jako łatwy. Wszystkie osoby, które określiły kontakt jako bardzo trudny, zamieszkiwały w dużych miastach powyżej 100 tys. mieszkańców. Wśród pacjentów deklarujących trudny i utrudniony kontakt z personelem większość, bo aż $60 \%$ zamieszkiwała na wsi.

Życie ze stomią wymaga od człowieka szerokiej wiedzy na temat choroby oraz zasad codziennego funkcjonowania $w$ jej przebiegu. Pacjent, który posiada dostateczną wiedzę oraz zna pozytywne przykłady innych osób z kolostomią, w pełni cieszących się życiem i aktywnie w nim uczestniczących, łatwiej przystosuje się do nowej sytuacji i ją akceptuje. 
Wśród 82 respondentów, 26 w pełni akceptowało stomię, niezupełnie akceptowało powyższą sytuację 34 badanych, a niespełna co 4 pacjent całkowicie jej nie akceptował.

Przynależność do Polskiego Towarzystwa Stomijnego zadeklarowało blisko $32 \%$ respondentów. Tylko 2 pacjentów należało do innych grup samopomocowych. Pozostałe 54 osoby nie zadeklarowały przynależności do żadnej grupy/stowarzyszenia. Wśród badanych należących do Towarzystwa Stomijnego, wszystkie osoby otrzymywały wsparcie od jego członków. W grupie tej zaobserwowano wysoki odsetek osób wskazujących na dobrą (73,08\%) i bardzo dobrą jakość życia (23,08\%). Tylko 1 osoby dotyczyła zła jakość życia (3,84\%).

Ustalenie poziomu jakości życia jest skomplikowanym i trudnym do interpretacji procesem, ponieważ wiąże się zawsze z subiektywną oceną stanu zdrowia oraz samopoczucia chorego. Analiza danych z ankiety wykazała, że prawie co czwarty respondent (21 osób) źle ocenił swoją jakość życia. W grupie tej znalazło się 15 kobiet oraz 6 mężczyzn. Najniższa liczba punktów, jaka dotyczyła wspomnianych respondentów wynosiła 20 a najwyższa 30 . Z kolei punktacja najliczniejszej grupy badanych (50 osób) znalazła się w przedziale 31 - 50 punktów, co odpowiadało deklaracji dobrej jakość życia. Wśród 50 ankietowanych było 19 kobiet oraz 31 mężczyzn. Najniższa liczba punktów jaką uzyskali respondenci $w$ tej grupie to 32 a najwyższa 50 .

Najmniej osób (11 ankietowanych), w tym 4 kobiety i 7 mężczyzn, uzyskało najwyższą punktację, co świadczyło o zakwalifikowaniu ich do grupy badanych z bardzo dobrą jakością życia. Respondenci otrzymali 51 - 54 punktów; żaden z nich nie uzyskał powyżej60 punktów.

Badani w teście satysfakcji osiągali minimum 20 punktów a maksymalnie 54 punkty, ze średnią $M=40$ punktów (z odchyleniem standardowym 9,5 punktu). 
Istotnym czynnikiem, determinującym zachowanie pacjenta ze stomią jest to, jak jest oceniany przez innych. Posiadanie kolostomii przeważnie nie upośledza funkcji organizmu, lecz świadomość jej społecznych skutków, negatywnych postaw otoczenia jest bardzo istotna. Chorzy bardzo często ograniczają lub wręcz wycofują się z pełnionych ról społecznych, życia towarzyskiego, aktywności, zainteresowań.

Wśród osób ze złą jakością życia tylko 3 respondentów $(14,29 \%)$ wskazywało na utrzymywanie podobnego poziomu kontaktów towarzyskich jak przed wyłonieniem stomii. Pozostali badani $(85,71 \%)$ oceniali ten aspekt swojego funkcjonowania jako nieco gorszy bądź znacznie gorszy. Z kolei w grupie pacjentów z dobrą i bardzo dobrą oceną jakości życia 47 osób (77,05\%) wskazało, że kontakty towarzyskie utrzymują na podobnym poziomie. Natomiast 5 respondentów oceniło je jako lepsze, 8 badanych jako nieco gorsze a tylko 1 ankietowany określił je jako znacznie gorsze. Zdaniem ponad połowy badanych kontakty towarzyskie były zatem podobne lub lepsze, a tylko u nielicznych a nich - nieco gorsze.

Osoby ze złą jakością życia nisko oceniły swój stan zdrowia. Na 21 aż 11 respondentów oceniło zdrowie jako nieco gorsze, a 7 jako gorsze. Tylko pojedynczy pacjenci wskazali na podobny czy lepszy stan zdrowia. Wydaje się, że często ocena ta dokonywana była przez pryzmat bólu fizycznego, którego częste odczuwanie w tej grupie zadeklarowało 11 badanych (52,38\%), rzadkie 10 osób (47,62\%). Wraz ze wzrostem jakości życia respondenci deklarowali stan zdrowia na podobnym poziomie jak przed operacji lub jego poprawę. Natomiast 16 osób $(76,19 \%)$ z niskim poziomem jakości życia zadeklarowało również częste ograniczenia w codziennych kontaktach osobistych, spowodowane obecnością stomii. Wraz ze wzrostem oceny poziomu jakości życia, przetoka stanowiła $\mathrm{w}$ tych kontaktach coraz mniejszą przeszkodę dla badanych. Bardzo nisko respondenci oceniali swoje kontakty seksualne po wyłonieniu stomii. Tylko jedna osoba $\mathrm{z}$ bardzo dobrą jakością życia oceniła je jako lepsze. W przypadku 
zdecydowanej większości osób ze złą jakością życia (95,24\%) były one znacznie gorsze. Równie nisko pacjenci oceniali swój wygląd zewnętrzny. Tylko w 3 przypadkach osób z dobrą jakością życia, własny wizerunek był oceniony jako lepszy, zdaniem 58,82\% badanych jako podobny. Pozostali respondenci wskazywali, że ich wygląd zewnętrzny jest nieco bądź znacznie gorszy. W przypadku pacjentów reprezentujących niski poziom jakości życia, tylko 1 oceniła swój wygląd jako podobny do okresu przed operacją. Zdaniem 47,62\% respondentów uległ on znacznemu pogorszeniu. Pozostali badani określili swój wizerunek jako nieco gorszy. Znacznie lepiej respondenci oceniali stosunek bliskich i znajomych do siebie (niezależnie od jakości życia). Tylko 2 badanych podało, że stosunek relacje te po wyłonieniu stomii są gorsze a 1 osoba wskazała, że znacznie gorsze. Według 2,53\% respondentów ich relacje z bliskimi i znajomymi po operacji były dużo lepsze, w opinii $22,78 \%$ osób lepsze. Pozostali badani wskazywali te relacje te są podobne jak przed wyłonieniem stomii.

Tylko w 3 badanych oceniło swoje warunki ekonomiczne po operacji jako lepsze. Przez pozostałych respondentów były one określane jako podobne lub nieco gorsze. Natomiast 8 respondentów ze złą jakością życia uznało, że ich sytuacja ekonomiczna jest znacznie gorsza. Opinie takie mogą wynikać z faktu pogorszenia stanu zdrowia, czasowej bądź stałej niezdolności do pracy, ponoszenia wydatków na sprzęt $w$ ramach zaopatrzenia stomijnego, zakupu środków do pielęgnacji, kosztów dojazdu na badania kontrolne.

W 82-osobowej grupie respondentów znajdowało się 38 kobiet, wśród których 23 prezentowały dobrą i bardzo dobrą jakość życia. W grupie 44 mężczyzn takie oceny dotyczyła także 38 respondentów. Analiza statystyczna $\mathrm{z}$ wykorzystaniem testu niezależności chi-kwadrat wykazała istotne statystycznie różnice w ocenie jakości życia przez badanych $\left(\operatorname{chi}^{2}(2)=7,04 ; p=0,031\right)$. Mężczyźni wyżej oceniali jakość swojego życia po wyłonieniu stomii w porównaniu do kobiet. 
Kolejnym czynnikiem, który poddano analizie statystycznej była aktywność zawodowa badanych. Wśród 51 emerytów aż 41 osób prezentowało dobrą i bardzo dobrą jakość życia. W grupie 20 pacjentów czynnych zawodowo 13 z nich swoją jakość życia po operacji oceniło jako dobrą i bardzo dobrą. Wśród 9 rencistów czterech z nich określiło swoją jakość życia jako dobrą a 1 jako bardzo dobrą. Analiza testem niezależności chi-kwadrat nie wykazała istotnych statystycznie różnic $\mathrm{w}$ ocenie jakości życia pacjentów po wyłonieniu kolostomii $\mathrm{z}$ uwagi na ich aktywność zawodową (chi² $(8)=8,97 ; p=0,262)$. Zróżnicowanie ocen jakości życia osób $\mathrm{w}$ tej grupie pacjentów nie wynikało istotnie $\mathrm{z}$ ich aktywności zawodowej.

Dokonano także analizy ocen jakością życia osób z wyłonioną kolostomią w zależności od sposobu ich zamieszkiwania. Większość respondentów (64 osoby - 78,05\%) mieszkało z bliskimi. Wśród 35 respondentów deklarujących zamieszkiwanie ze współmałżonkiem, 27 osób cieszy się dobrą i bardzo dobrą jakością życia. Natomiast spośród 15 osób mieszkających ze współmałżonkiem i dziećmi, tak wysokie oceny jakości życia wskazywało 14 badanych. Z kolei w grupie 14 respondentów zamieszkujących z dziećmi i wnukami, połowa z nich oceniała jakość swojego życia jako dobrą i bardzo dobrą. Natomiast wśród 18 osób (21,95\%), które zadeklarowały samotne prowadzenie gospodarstwa domowego aż 13 wskazywało na dobrą i bardzo dobrą jakość życia. Przeprowadzona analiza testem niezależności chi-kwadrat nie wykazała istotnych statystycznie różnic w ocenie jakości życia respondentów w zależności od sposobu ich zamieszkania $\left(\operatorname{chi}^{2}(6)=8,59 ; \mathrm{p}=0,177\right)$.

Wśród 10 respondentów $\mathrm{z}$ wykształceniem podstawowym tylko $4 \mathrm{z}$ nich (40\%) zadeklarowało dobrą i bardzo dobrą jakość życia po operacji. W grupie 26 ankietowanych z wykształceniem zawodowym, równie wysoką ocenę jakości życia prezentowało 14 pacjentów (53,85\%). Dobra i bardzo dobra jakość życia dotyczyła 19 respondentów $(63,33 \%)$ z 30-osobowej grupy osób ze średnim 
wykształceniem. Natomiast wszyscy badani z wyższym wykształceniem (16 osób -100\%) dokoali tak wysokiej oceny jakości życia. Analiza korelacji rho-Spearmana wykazała istotne statystycznie różnice pomiędzy poziomem jakości życia a wykształceniem pacjentów. Oznacza to, że istotnie wyższy poziom jakości życia prezentowali respondenci lepiej wykształceni.

Z grupy pacjentów mieszkających w miastach (58 osób70,73\%), aż 48 osób (82,76\%) zadeklarowało dobrą i bardzo dobrą jakość życia. Taką samą ocenę wskazało 15 mieszkańców wsi $(62,5 \%)$. Analiza korelacji rho-Spearmana wykazała istotne statystycznie różnice pomiędzy poziomem jakości życia respondentów a miejscem ich zamieszkania. Wyższy poziom jakości życia istotnie częściej dotyczył mieszkańców dużych miast.

Wsparcie społeczne jest rodzajem kontaktów społecznych, które zmierzają do przezwyciężenia trudności i problemów występujących u osoby wspieranej. Umożliwia ono zwiększenie samooceny, poczucia własnej wartości, co stanowi ważny czynnik motywujący do przezwyciężenia trudności. Wskazując źródła wsparcia respondenci podkreślali tutaj szczególnie udział rodziny (75,61\% badanych) a także znajomych, pracowników ochrony zdrowia, członków grup samopomocowych i POL -ILKO. Analiza korelacji rhopearmana wykazała wyższy poziom jakości życia respondentów, którzy otrzymywali wsparcie społeczne po wyłonieniu stomii.

\section{Dyskusja}

Jak wcześniej wspomniano, ustalenie poziomu jakości życia wiąże się zawsze z subiektywną oceną swojego stanu zdrowia oraz samopoczucia dokonywaną przez pacjenta. Jak zauważył w swojej pracy Jawień i wsp., uzyskanie wiarygodnych wyników byłoby możliwe tylko dla podobnych grup chorych, z podobnie prowadzonym procesem leczenia oraz ze zbliżonymi stanami zaawansowania choroby [6]. Należy bowiem pamiętać, że podobne objawy mogą 
odmiennie wpływać na jakość życia osób różniących się stylem życia czy wiekiem. Z drugiej strony odczuwany przez chorych komfort życia z dolegliwościami o różnym nasileniu może być podobny [6]. Na zróżnicowanie oceny mają również wpływ narzędzia badawcze, których różnorodność może powodować trudności w porównywaniu wyników badań oraz uogólnieniu wniosków. Warto podzielić pogląd Jaracz, że nie ma dotychczas uniwersalnego, a zarazem doskonałego narzędzia badawczego do oceny jakości życia [7].

Liczne badania dowiodły, że u osób z wyłonioną kolostomią obserwuje się obniżoną jakość życia. Zjawisko to potwierdziły również badania własne, gdzie dobrą i bardzo dobrą jakość życia stwierdzono tylko u 74,39\% respondentów. Posługując się tym samym kwestionariuszem Banaszkiewicz i wsp. w badaniach przeprowadzonych na przełomie 2002/2003 roku na 60-osobowej grupie chorych, wykazali, że taka ocena dotyczyła $86 \%$ respondentów [8]. Z kolei w badaniach Leyk i wsp. [9] średni poziom jakości życia badanych wahał się w granicach zaledwie $69 \%$. Równie niski wynik otrzymały w swych badaniach Wrońska i Wiraszka [10], które posługiwały się tym samym narzędziem badawczym co Leyk.

Obawa przed ludzką niechęcią, społecznym odrzuceniem, prowadzi często do wycofania się z życia towarzyskiego, ograniczeń w pracy zawodowej i wykonywaniu codziennych czynności, zainteresowań, pasji czy korzystania z rozrywek. W badaniach własnych tylko nieliczne osoby, które charakteryzowała dobra czy bardzo dobra jakość życia wskazały na poprawę kontaktów towarzyskich po wyłonieniu stomii. Pozostali respondenci podkreślali, że nie zmieniły się one lub są na gorszym poziomie. Podobnie sytuacja dotyczy samoooceny stanu zdrowia, odczuwania bólu czy obecności stomii jako przeszkody $\mathrm{w}$ codziennych kontaktach osobistych. Im niższej oceny jakości życia dokonywali respondenci, tym mniej punktowane odpowiedzi zostawały przez nich zaznaczane. Podobne wyniki uzyskał swoich badaniach Banaszkiewicz i wsp. [8]. 
W badaniach własnych wyższa ocena jakości życia po wyłonieniu kolostomii istotnie częściej dotyczyła mężczyzn. Również w badaniach Banaszkiewicza i wsp. zaobserwowano 3 - krotnie częściej bardzo dobrą jakość życia u mężczyzn, jednak w tym przypadku różnice nie były istotne statystycznie [8]. Lepsze wyniki mężczyzn w ocenie jakości życia potwierdzają również $\mathrm{w}$ swych badaniach Plata i Majewski [11] oraz Podgórska - Kowalczyk [12]. W piśmiennictwie dominuje pogląd, że mężczyźni łatwiej adaptują się do życia z kolostomią niż kobiety. Wynika to przede wszystkim z faktu, że dla samooceny kobiety jej wygląd zewnętrzny ma większe znaczenie niż dla płci przeciwnej [8].

W badaniach nie wykazano istotnych statystycznie różnic w ocenie jakości życia pacjentów po wyłonieniu kolostomii z uwagi na ich aktywność zawodową. W badaniach Banaszkiewicza i wsp. także nie stwierdzono różnic istotnych statystycznie, chociaż w grupie osób wykonujących prace umysłową, odsetek badanych z najlepszą jakością życia był 2 - krotnie wyższy niż w pozostałych grupach [8].

Człowiek, u którego w efekcie choroby wytworzono stomię będzie musiał nauczyć się z nią żyć. Czy po powrocie do domu, jeśli będzie miał przy sobie na co dzień kogoś bliskiego łatwiej mu będzie zaakceptować siebie, swoją chorobę i jej następstwa? Wyniki badań własnych nie wykazała istotnych statystycznie różnic w ocenie jakości życia respondentów w zależności od sposobu ich zamieszkania. Jednak w badaniach Banaszkiewicza i wsp., podobnie jak w pracy własnej, stwierdzono wysoki odsetek pacjentów z dobrą/bardzo dobrą oceną jakości życia w przypadku wspólnego zamieszkania z liczną rodziną [8]. W grupie pacjentów żyjących samotnie nie stwierdzono osób $\mathrm{z}$ bardzo wysoką satysfakcją. Występujące różnice $\mathrm{w}$ obydwu badaniach wprawdzie nie były istotne statystycznie, ale wskazują, że obecność bliskich wpływa jednak pozytywnie na ocenę pacjentów w zakresie przystosowania się do nowej sytuacji, zmodyfikowanej chorobą. 
Choroba nowotworowa pozostaje $\mathrm{w}$ dalszym ciągu jedną z najczęstszych przyczyn wyłonienia stomii. Wśród 82 respondentów aż 63 osoby $(76,83 \%)$ miały wyłonioną przetokę z tego powodu. $\mathrm{W}$ pozostałych przypadkach były to inne przyczyny. Nie potwierdzono $\mathrm{w}$ analizie statystycznej istotnej współzależności między jakością życia a przyczyną wytworzenia kolostomii, co potwierdzaja także badania Banaszkiewicza i wsp. W badaniach autorów wykazano bardzo podobny odsetek chorych, u których wyłoniono stomię z powodu raka jelita grubego (80\%) [8]. Niższy poziom jakości życia pacjentów w badaniach w 2002 roku wykazała Wrońska i Wiraszka. Uczestniczyły w nich tylko osoby z wyłonioną definitywną kolostomią w następstwie choroby nowotworowej. Można przypuszczać, że rozpoznany rak jelita grubego oraz zmęczenie i wyniszczenie towarzyszące leczeniu uzupełniającemu (chemioterapia, radioterapia), stanowią dodatkową przyczynę obniżenia jakości życia pacjentów ze stomią [10].

Dokonując analizy jakości życia $\mathrm{z}$ uwzględnieniem wieku Banaszkiewicz i wsp. w grupie badanych po 60 roku życia stwierdzili 3 - krotnie więcej respondentów, którzy dokonywali bardzo dobrej oceny jakości życia. Różnice te nie były również istotne statystycznie [8]. Podgórska - Kowalczyk w swojej pracy wykazała jednak znaczące różnice i doszła do wniosku, że wiek jest istotnym czynnikiem determinującym jakość życia. Według autorki, osoby starsze wyżej oceniają swoje położenie życiowe niż badani w innych grupach wiekowych [12].

W badaniach własnych istotnie wyższy poziom jakości życia prezentowali respondenci lepiej wykształceni. W badaniach Banaszkiewicza i wsp., chociaż nie stwierdzono istotnych statystycznie różnic, to zwrócono uwagę na fakt, że wśród osób z najniższym wykształceniem, połowa z nich prezentowała najgorsze oceny jakości życia. Natomiast w grupie osób z wykształceniem wyższym nie było ani jednej osoby z taką oceną [8]. 
Z badań własnych wynika, że wyższy poziom jakości życia istotnie częściej dotyczył mieszkańców dużych miast. Podobnie wyniki uzyskano $\mathrm{w}$ badaniach przeprowadzonych przez Banaszkiewicza i wsp., gdzie $70 \%$ osób mieszkało w miastach i $30 \%$ na wsi. Pomimo, że nie stwierdzono istotnych statystycznie zależności to ustalono, że w małych i średnich miastach odsetek pacjentów ze złą oceną jakości życia był większy [8]. Sytuacja taka wydaje się być związana z trudniejszym dostępem do poradni stomijnych zapewniających specjalistyczną opiekę pooperacyjną, klubów stomijnych, grup samopomocowych, klubów stomijnych czy wreszcie oddziałów towarzystw POL - ILKO. Placówki takie oraz siedziby stowarzyszeń znajdują się najczęściej w największych miastach. W naszym kraju istnieje niestety wciąż za mało poradni dla pacjentów ze stomią, które stanowią często jedyne miejsce uzyskania pomocy i wsparcia [8]. Niedostatek takich placówek przekłada się na różne aspekty jakości życia osób z wyłonioną stomią.

Wyniki badań własnych wskazują, że wyższy poziom jakości życia dotyczył respondentów, którzy otrzymywali wsparcie społeczne po wyłonieniu stomii. Należy także podkreślić, że wszystkie osoby deklarujące przynależność do Towarzystwa Stomijnego otrzymywały wsparcie od jego członków i tylko jednego respondenta z tej grupy dotyczyła zła ocena jakości życia. Wielu autorów publikacji także nie ma wątpliwości, co do potrzeby istnienia wsparcia $\mathrm{w}$ życiu człowieka, szczególnie tego, który znalazł się w trudnej sytuacji [14]. W badaniach Wojtyny i wsp. [15] udowodniono, że doznawanie wsparcia emocjonalnego wiąże się z niższym poziomem dystresu, depresji, odczuwanego bólu oraz może pozytywnie wpływać na przystosowanie pacjenta do choroby, przyspieszenie powrotu do zdrowia, a co za tym idzie na poziom odczuwanej satysfakcji $[16,17]$. $\mathrm{Na}$ rodzinę jako źródło wsparcia emocjonalnego zwrócili uwage w swoich badaniach Ponczek, Nowicki, Zegarski i wsp. Potwierdzili oni, że wsparcie otrzymywane od współmałżonka wpływa na poprawę funkcjonowania emocjonalnego chorego [18]. Również 
badania Leyk, Książek oraz Stangiewicza potwierdziły występowanie u pacjentów wysokiego poziomu wsparcia dostępnego (spostrzeganego przez nich), a równocześnie dowiodły, że poziom spostrzeganego wsparcia jest równy poziomowi wsparcia faktycznie otrzymywanego przez chorych [17]. Na istotną rolę wsparcia zwrócił również uwagę $\mathrm{w}$ swojej pracy Banaszkiewicz i wsp., który w kontakcie chorego $\mathrm{z}$ drugim człowiekiem upatruje pozytywnych zmian w sferze psychicznej [8].

Reasumując, pomoc i obecność osoby wspierającej pozwala otworzyć się na siebie, świat, innych ludzi. Wsparcie powoduje, że często egoistyczne skupienie się na własnym bólu, problemach zostaje zastąpione szacunkiem do siebie, że udało się przezwyciężyć kryzys [8].

\section{Wnioski}

1. Obniżony poziom jakości życia pacjentów $\mathrm{z}$ wytworzoną kolostomią może wynikać zarówno z obiektywnych czynników społeczno - ekonomicznych, klinicznej oceny choroby jak i subiektywnej oceny samopoczucia oraz zdolności do dalszego funkcjonowania w różnych dziedzinach życia.

2. Czynniki socjo - demograficzne takie jak: płeć, wykształcenie, miejsce zamieszkania wywierają istotny wpływ na ocenę jakości życia wśród pacjentów z wyłoniona kolostomią.

3. Wsparcie społeczne istotnie wpływa na oceną jakości życia pacjentów z kolostomią. Szczególne znaczenie ma przynależność pacjentów do Polskiego Towarzystwa Stomijnego oraz wsparcie otrzymywane od jego członków.

\section{Zalecenia dla praktyki pielęgniarskiej}


Częstotliwość i charakter relacji $\mathrm{z}$ pacjentem $\mathrm{z}$ wyłonioną kolostomią, stwarzają pielęgniarce okazję do udzielania różnych form wsparcia w ramach realizowanych świadczeń zdrowotnych. Wzmacnianie potencjału jego wiedzy i umiejętności $\mathrm{z}$ zakresu samoopieki w związku $\mathrm{z}$ wyłonioną kolostomią oraz towarzyszące wsparcie społeczne, będą sprzyjać adaptacji pacjenta do nowej sytuacji zdrowotnej i optymalizacji jakości jego życia.

\section{Bibliografia/Bibliography:}

1. Cierzniakowska K., Szewczyk M.T., Stodolska A., Banaszkiewicz Z., Jawień A. Zapobieganie powikłaniom skórnym wokół stomii, Magazyn Pielęgniarki i Położnej. 2005; 3:33.

2. Banaszkiewicz Z., Jawień A. Stomie jelitowe. Przewodnik Lekarza. 2003;10:89.

3. Szewczyk M.T., Cierzniakowska K., Cwajda J., Stodolska A., Jawień A., Banaszkiewicz Z. Opieka nad chorym z raną wokół stomii. Przewodnik Lekarza. 2005; 4: 92-93, 95.

4. Michalak S., Cierzniakowska K., Banaszkiewicz Z., Szewczyk M.T., Jawień A. Ocena przystosowania się chorych do życia ze stomią jelitową. Pielęgniarstwo Chirurgiczne i Angiologiczne. 2008;3: 91 - 92.

5. Szewczyk J., Bajon A. Opieka pielęgniarska w okresie okołooperacyjnym nad pacjentem $\mathrm{z}$ wyłonioną stomią jelitową, Polski Merkuriusz Lekarski. 2009; XXVI: .575 - 576.

6. Jankowski M., Banaszkiewicz Z., Jawień A. Jakość życia osób ze stomią. Valentudinaria - Postępy Medycyny Klinicznej i Wojskowej. 2004; (9)2: 125 $-126$.

7. Chrobak A. Pielęgniarka jako edukator pacjentów z wyłonioną stomią jelitową. Polski Merkuriusz Lekarski. 2009; XXVI: 579 - 580. 
8. Banaszkiewicz Z., Szewczyk M.T., Cierzniakowska K., Jawień A. Jakość życia osób ze stomią jelitową. Współczesna Onkologia. 2007;11: 17 - 23.

9. Leyk M., Książek J., Piotrkowska R., Terech S., Kruk A. Jakość życia osób z wyłonioną kolostomią. Pielęgniarstwo Chirurgiczne i Angiologiczne. 2007;3:77.

10. Wrońska I., Wiraszka G. Jakość życia chorych z rakiem jelita grubego i wytworzonym brzusznym odbytem. Psychoonkologia. 2003; 7: 37 - 39.

11. Plata K., Majewski W. Jakość życia pacjentów po zabiegu operacyjnym na jelicie grubym z wytworzeniem stomii i możliwości jej poprawy. Rocznik Pomorskiej Akademii Medycznej w Szczecinie. 2008; 54; 2: 83.

12. Podgórska - Kowalczyk D. Ocena jakości życia chorego ze sztucznym odbytem brzusznym na podstawie wybranych czynników obiektywnych i subiektywnych. Zdrowie Publiczne. 2005;115(2):151 -153.

13. Glińska J., Hebda A., Dziki A. Wpływ opieki pielęgniarskiej na jakość życia pacjentów ze stomią jelitową. Proktologia. 2005; 6 (3):233.

14. Bazaliński D., Kózka M., Czupryna A. Występowanie późnych powikłań po wyłonieniu przetoki jelitowej (stomii). Pielęgniarstwo XXI wieku. 2006; 4(17):135 - 136.

15. Wojtyna E., Dosiak M., Życińska J. Wpływ wsparcia społecznego na przebieg zaburzeń depresyjnych u pacjentów $\mathrm{w}$ podeszłym wieku. Psychogeriatria Polska. 2007;4:17 - 26.

16. Kurowska K., Kościelna H. Orientacja życiowa a wsparcie społeczne u osóbz kolostomią wyłonioną z powodu raka jelita grubego. Współczesna Onkologia. 2008; 12(5):232.

17. Leyk M., Książek J., Stangiewicz M. Rodzina jako źródło wsparcia społecznego dla osób $\mathrm{z}$ wyłonioną kolostomi. Problemy Pielęgniarstwa.2010;18(1): $42-45$. 
18. Ponczek D., Nowicki A., Zegarski W. i wsp. Ocena jakości życia u chorych leczonych chirurgicznie z powodu raka odbytnicy w aspekcie czynników społeczno-demograficznych. Współczesna Onkologia. 2006; 10: 164 - 170.

Otrzymano: 25.04 .2019 r.

Zaakceptowano: $20.05 .2019 \mathrm{r}$. 